\title{
Is Economic Volatility Detrimental to Global Sustainability?
}

\author{
Yongfu Huang
}

In a dynamic panel data model allowing for error cross-section dependence, output volatility is found to impede sustainable development. Through a financial development channel (liquidity liability ratio), output volatility exerts a significant effect on depletion of natural resources, a key component of sustainability. Low-income countries, low energy-intensity countries, and low trade-share countries tend to be especially vulnerable to macroeconomic volatility and shocks. The findings highlight the interaction between global financial markets and the wider economy as a key factor influencing sustainable development, with important implications for macroeconomic and environmental policies in an integrated global green economy. JEL codes: E32, O11, O16

The world economy grew at an average annual rate of 2.7 percent in the 1990s and then performed exceptionally well over 2000-08, growing at an average annual rate of 3.2 percent a year (World Bank 2010b). Following these long economic boom periods, the world economy, especially financial markets, experienced a period of uncertainty, volatility, and severe crises. At the same time, climate change, in large part due to human activities (IPCC 2001), began to emerge clearly as the greatest global challenge of our age. Between 1981 and 2005, some 60 percent of the world's ecosystems became degraded or were being unsustainably exploited (Barbier 2009). This suggests an important question: Could economic volatility lead countries down an unsustainable path?

Against a background of multiple crises-climate, fuel, food-the global financial crisis of 2007-09 has caused enormous damage to the world

Yongfu Huang (yh279@cam.ac.uk) is a Tyndall Research Fellow at the University of Cambridge. The author is grateful to Philip Arestis, Unai Pascual, Vasilis Sarafidis, the journal editor, and three anonymous referees for constructive comments and suggestions. He also thanks two Tyndall Centre referees and seminar participants at the Department of Land Economy of Cambridge University for helpful comments and discussions. A supplemental appendix to this article is available at http://wber. oxfordjournals.org/.

THE WORLD BANK ECONOMIC REVIEW, VOL. 26, NO. 1, pp. 128-146

doi:10.1093/wber/lhr042

Advance Access Publication October 27, 2011

(C) The Author 2011. Published by Oxford University Press on behalf of the International Bank for Reconstruction and Development / THE WORLD BANK. All rights reserved. For permissions, please e-mail: journals.permissions@oup.com 
economy, resulting in the most severe global recession in generations. The financial crisis spread rapidly around the globe. Nearly all stock markets experienced bursts of volatility. Lin (2009, p. 2) points out that the current economic downturn is "possibly turning a short-run macroeconomic adjustment into a long-term development problem." But empirical evidence on the impact of economic volatility on long-run sustainable development remains sparse.

This article looks at whether economic volatility has a damaging effect on sustainable development, as measured by changes in genuine savings or adjusted net savings (net national savings minus natural resource depletion). Research on the link between volatility and growth indicates a significant impact of volatility on savings through growth. To determine whether the link between volatility and sustainability reflects more than the link between volatility and savings, this article goes a step further to examine whether output volatility affects natural resource depletion.

A dynamic panel data study was conducted with data for 128 countries over 1979-2008. To address the effects of global shocks in recent decades-driven by the increases in international trade and private capital flows-that could cause error dependence across countries, the study considers a common factor structure in the error term. More specifically, it applies the system of generalized method of moments (GMM), adjusted to allow for error cross-section dependence (Sarafidis and others 2009).

The study finds that output volatility exerts a strong negative impact on genuine savings. The impact is strongest in low-income countries, low energy-intensive countries, and low trade-share countries. In addition to the significant impact of volatility on savings suggested in the literature, it finds that the negative effect of output volatility on genuine savings is due to the positive impact of output volatility on natural resource depletion through a financial development channel (liquidity liability ratio). The findings highlight the role of the interaction between global financial markets and the wider economy in promoting global sustainability.

This article contributes to the literature in several dimensions. First, it explores the effects of output volatility on both genuine savings and the depletion of natural resources. Second, it allows for the possibility of error cross-section dependence and tries to correct for reverse causality and unobserved country-specific effects. Third, it considers macroeconomic and environmental policies in an integrated global green economy in which development strategies and programs take account of the state of natural resources (energy, forests, minerals, soils, freshwater, and fisheries) on which future growth depends.

Section I reviews the literature. Section II describes the data and outlines the methodology of GMM estimation without and with cross-section dependence. Section III details the empirical results. Section IV presents some implications of the findings. 


\section{The Theoretical and Empirical Research on Volatility, Growth, And Sustainability}

Volatility measures the variation or movement in an economic variable such as the growth rate, usually by a standard deviation of the variable over some period. Volatility has declined in general over recent decades, but as an independent research area, it has moved from a second-order concern to "a central position in development economics" (Aizenman and Pinto 2005, p. 2). There is considerable research on the link between economic volatility and long-run growth, along with considerable controversy. ${ }^{1}$ Since high growth performance does not necessarily lead to high levels of development, policymakers have increasingly emphasized sustainable development as the primary national objective, especially for developing countries. Sustainable development-a different kind of growth that preserves the environment-is about economic growth together with environmental protection, with the two reinforcing each other. ${ }^{2}$ It is thus important to understand the impact of economic volatility on sustainable development.

The research references the widely used sustainability indicator of genuine savings. Based on standard national accounting conventions, genuine savings considers depletion of natural resources, pollution damage, and investments in human capital. It is the true savings rate in an economy in terms of creating and maintaining total net wealth, which is inclusive of manufactured capital, human capital, and natural capital. In recent years, considerable research has tried to explain differences in genuine savings rates across countries, identifying several variables, such as per capita gross national income, per capita GDP growth rate, age dependency, and urbanization (Dietz and others 2007).

Research indicates a significant impact, positive or negative, of volatility on savings through growth; however, the impact of volatility on natural resources depletion, a key element of genuine savings, is not yet well understood. It is still not clear whether the impact of volatility on genuine savings is due to the impact of volatility on natural resources depletion.

If output volatility does play a role in natural resources depletion, what are the channels? Potentially, volatility could accelerate natural resources depletion and environmental degradation through financial markets, trade, or investment;

1. One line of theoretical research finds that volatility is positively related to growth (Sandmo 1970; Ghosh and Ostry 1997; Canton 2002). Another line of research supports a negative impact of volatility on growth (Kharroubi 2007; Aysan 2007). Empirically, while Kormendi and Meguire (1985) and Grier and Tullock (1989), among others, find evidence that output volatility promotes growth, most cross country studies suggest that economic volatility hurts long-run growth (Ramey and Ramey 1995; Hnatkovska and Loayza 2005; Loayza and others 2007; Koren and Tenreyro 2007).

2. According to the World Commission on Environment and Development (1987, ch. 2), sustainable development is "a development path that meets the needs of the present without compromising the ability of future generations to meet their own needs." It has typically been regarded as having three dimensions or pillars—environmental, social and economic sustainability-which are not mutually exclusive and can be mutually reinforcing (United Nations 2005). 
however, these channels have not been carefully examined. ${ }^{3}$ For financial markets, generally speaking, global economic volatility is likely to increase credit risk and uncertainty. The loss of confidence means that investors are likely to refuse to provide funds to banks, while the banks tend to ration borrowers by providing less credit than requested or restricting loan maturity. ${ }^{4}$ The credit crunch reduces investment in energy sectors and low-carbon projects and discourages switching to low-carbon and renewable energy technologies that conserve natural resources and are less environmentally destructive but that are typically more costly than conventional technologies (OECD/IEA 2009). With companies unable to fund capital-intensive offset projects in either regulated or voluntary carbon markets, the credit crunch slows development of global carbon markets, which are designed to achieve the dual objectives of sustainable development and emission reductions. ${ }^{5}$ The credit crunch also leads to severe funding cuts for environmental agencies and initiatives to tackle environmental problems such as deforestation (Kittiprapas 2002; Kasa and Næss, 2005). Finally, the curtailed availability of credit and insurance also reduces trade and investment flows in the natural resources sectors (Committee of Ten 2009).

The economic crisis and volatility could also affect natural resources depletion through unemployment and weaker enforcement of environmental law. Dauvergn (1999) shows that the lost jobs and falling income associated with financial crisis could trigger greater natural resources extraction as people in poor and densely populated countries revert to ecological commons such as fisheries and forests to secure basic subsistence. With detailed survey data, Gaveau and others (2009) find that the 1997-98 crisis caused a reversal in law enforcement efforts in Indonesia, resulting in substantial losses of "protected" forests and biodiversity.

This study aims to contribute to this emerging line of research.

\section{Data and Methodology}

This study examines whether economic volatility has significant impacts on sustainable development, controlling for per capita GDP growth, per capita gross national income (GNI), and the age-dependency ratio (ratio of

3. Several transmission channels for the effect of volatility on growth have been studied. Wolf (2005) discusses factor accumulation, domestic finance, trade, capital mobility, and political institutions. In addition, Ramey and Ramey (1995) emphasize the level of investment, while Aysan (2007) supports the productivity of investment rather than its level.

4. Huang (2011, p. 45) provides evidence that output volatility (and volatility of the black market premium) has a negative impact on the total size of the financial system (banking sector plus stock market) in the developing world.

5. Hamilton and others (2010) indicate that, due to the financial crisis, global voluntary carbon markets transactions declined 26 percent and their total value dropped 47 percent in 2009 compared with 2008. 
dependents to working-age population). ${ }^{6}$ Appendix Table S1 in the supplemental appendix (available at http://wber.oxfordjournals.org/) describes the variables and lists their sources.

\section{The Data}

The first dependent variable is "genuine savings," or adjusted net saving excluding particulate emission damage, ${ }^{7}$ (GENSAV) as a percent of GNI. (The data for all variables, unless otherwise noted, are from World Bank 2010b.) The regressions use three-year averages over 1979-2008 of $\log (1+$ GENSAVI 100).

The second dependent variable is "resource depletion" (DEPLETION), or the value of net national savings plus education expenditure, minus adjusted net saving and carbon dioxide damage. The regressions use three-year averages over 1979-2008 of $\log (1+$ DEPLETION/100).

This analysis focuses mainly on "output volatility" (VGR), defined as the standard deviation for three-year intervals over 1979-2008 of $\log (1+G R /$ 100).

The analysis controls for "per capita GDP growth" (GR), "per capita GNI" (GNIPC), and "age-dependency ratio" (AGE). The analysis uses three-year averages over 1979-2008 of $\log (1+G R / 100), \log (1+G N I P C / 100)$, and $\log (1+A G E / 100)$.

Two potential channels of transmission are investigated: "liquidity liability ratio" (LLY) and "investment" (KI). LLY, the financial channel, measures the liquid liabilities of banks and nonbank financial intermediaries (currency plus demand and interest-bearing liabilities) as a share of GDP. It reflects the size of financial intermediaries relative to the economy, including the central bank, deposit money banks, and other financial institutions. The analysis uses $\log (100 \times L L Y)$. KI, the investment channel, is the percentage share of investment in real GDP per capita (RGDPL). The regressions use $\log (R G D P L)$ and $\log (K I)$. The data are from Heston, Summers, and Aten (2009).

The sample contains data for 128 nontransition economies over 1979-2008 (listed in table S2 in the supplemental appendix), with non-overlapping threeyear periods, so that each country has a maximum of 10 observations. Countries with fewer than 10 annual observations are excluded. The

6. Although the life expectancy ratio and the urbanization rate were also considered as controlling variables, and energy use per capita and final energy intensity as potential channels, no evidence was found for them. Data on life expectancy at birth (total years), urban population (percent of total), and energy use per capita (kilograms of oil equivalent per capita) are from World Bank (2010b). Data on final energy intensity are from Enerdata (2010).

7. The adjusted net savings series is equal to net national savings (gross savings less depreciation of produced assets) plus investment in human capital (education expenditure) minus resource depletion (energy depletion, mineral depletion, net forest depletion) and environmental degradation (carbon dioxide). Since there are more missing values when adjusted net savings includes particulate emission damage, this analysis uses adjusted net savings excluding particulate emission damage. 
regressions include dummy variables for 31 low-income countries, 63 low- and middle-income countries, 65 countries whose average final energy intensity of GDP at purchasing power parity over the period is below the median ("lower energy intensity countries"), and 70 countries whose average trade share as a percent of GDP over the period is below the median ("lower trade-share countries"). Income classifications are from the World Bank (2011). Data on final energy intensity of GDP are from Enerdata (2010).

\section{Methodology}

This analysis of the impact of economic volatility on sustainable development under globalization employs the GMM estimator adjusted to allow for error cross-section dependence, recently proposed by Sarafidis, Yamagata, and Robertson (2009) for a linear dynamic panel model.

In recent decades, cross-country dependence has become an important phenomenon in an increasingly globalized world where common factorsmacroeconomic shocks, common technological shocks, and environmental shocks-can cause strong interactions in the world economy. The following model allows for error cross-section dependence:

$$
\begin{aligned}
\operatorname{DEPVAR}_{i t}= & \gamma_{i}+\alpha \mathrm{DEPVAR} \\
& +\beta_{3, t-1}+\beta_{1} \operatorname{VNIPC}_{i, t-1}+\beta_{2} \mathrm{GR}_{i, t-1} \\
& i=1,2, \cdots, 128 ; t=2, \cdots \mathrm{\beta}_{i t}+\lambda_{i}^{\prime} f_{t}+v_{i t} \\
& i=10
\end{aligned}
$$

where DEPVAR denotes the dependent variable, GENSAV or DEPLETION, and $\gamma$ is individual effects. The autoregressive coefficient $\alpha$ is assumed to lie inside the unit circle, $|\alpha|<1$, to ensure model stability. The coefficients $\beta_{1}$ to $\beta_{4}$ reflect the existence and direction of any specific effect on GENSAV or DEPLETION. The term $f_{t}$ is a $(r \times 1)$ vector of unobserved time-varying common factors assumed to be nonstochastic and bounded, and $\lambda_{i}$ is a vector of factor loadings assumed to be independent and identically distributed, such that $\lambda_{i}^{\prime} f_{t}=\lambda_{i 1} f_{t 1}+\lambda_{i 2} f_{t 2}+\ldots+\lambda_{i r} f_{t r}$ (here $r$ is the number of common factors). ${ }^{8}$ The error term $v_{i t}$ is the transitory disturbance term, which is assumed to be independently distributed with zero mean and finite variance. It is also assumed to be uncorrelated with individual effects and common factors, but correlations are possible between either individual effects or common factors ( $f_{t}$ and subsequent shocks) and the regressors.

The explanatory variables $V G R_{i, t-1}, G R_{i, t-1}$, and $G N I P C_{i, t-1}$ are predetermined with respect to $v_{i t}$ and so may be correlated with $v_{i, t-1}$ and earlier shocks, but they are uncorrelated with $v_{i t}$ and subsequent shocks. The

8. Bai (2009) suggests an interactive effects model that includes the interaction between factors, $f_{t}$, and factor loadings, $\lambda_{i}$, which is more general than an additive effects model, the traditional one-way

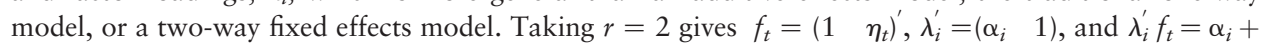
$\eta_{t}$, where $\alpha_{i}$ is the individual effect and $\eta_{t}$ is the time effect. 
assumption of predetermination for the explanatory variables other than $A G E_{i t}$ rules out the possibility of reverse causality or joint determination.

The first-differences of equation (1) are

$$
\begin{aligned}
\Delta \text { DEPVAR }_{i t} & =\alpha \Delta D E P V A R_{i, t-1}+\beta_{1} \Delta V G R_{i, t-1}+\beta_{2} \Delta G R_{i, t-1} \\
& +\beta_{3} \Delta G N I P C_{i, t-1}+\beta_{4} \Delta A G E_{i t}+\lambda_{i}^{\prime} \Delta f_{t}+\Delta v_{i t} \\
& i=1,2, \cdots, 128 ; t=3, \cdots 10
\end{aligned}
$$

where $\triangle D E P V A R_{i t}=D_{E P V A R}{ }_{i t}-D E P V A R_{i, t-1}$, which applies to $\triangle A G E_{i t}$ $\Delta V G R_{i, t-1}=V G R_{i, t-1}-V G R_{i, t-2}$, which also applies to $\Delta G R_{i, t-1}$ and $\Delta$ GNIPC $_{i, t-1} \Delta f_{t}=f_{t}-f_{t-1}$ and $\Delta v_{i t}=v_{i t}-v_{i, t-1}$.

When common factors are assumed to have an identical effect on each crosssection unit, several methods have been proposed using first differencing to eliminate the individual effects when estimating dynamic panel data models with a short time dimension. Arellano and Bond (1991) propose the firstdifferenced GMM estimator (DIF-GMM). ${ }^{9}$ For simplicity, $y_{i t}$ denotes $D E P V A R_{i t}$ and $x_{i t}$ is a vector of independent variables $\left(V G R_{i t}, G R_{i t}, G N I P C_{i t}\right.$, $\left.A G E_{i t}\right)$. The moment conditions for errors in differences on which the DIF-GMM estimator in this application is based can be written as

$$
\begin{aligned}
& E\left[\left(\begin{array}{l}
y_{i}^{t-2} \\
x_{i}^{t-2}
\end{array}\right)\left(\Delta v_{i t}\right)\right]=0 \\
& t=3, \cdots 10
\end{aligned}
$$

where $y_{i}^{t-2}=\left(y_{i 1}, y_{i 2}, \ldots y_{i, t-2}\right)^{\prime}$ and $x_{i}^{t-2}=\left(x_{i 1}, x_{i 2}, \ldots x_{i, t-2}\right)^{\prime}$.

The DIF-GMM estimator has been found to suffer from the weakinstruments problem associated with highly persistent data. To address this issue, Arellano and Bover (1995) and Blundell and Bond (1998) developed a system GMM estimator (SYS-GMM) by considering a mean stationarity assumption on initial conditions. In addition to the moments for errors in differences described above, the SYS-GMM estimator is also based on the additional moments for errors in levels as follows: ${ }^{10}$

$$
\begin{aligned}
& E\left[\left(\begin{array}{c}
\Delta y_{i, t-1} \\
\Delta x_{i, t-1}
\end{array}\right)\left(\gamma_{i}+v_{i t}\right)\right]=0 \\
& t=3, \cdots 10
\end{aligned}
$$

However, in reality, common factors typically have a differential effect across

9. DIF-GMM uses all lagged values of the dependent variable and independent variables from $t-2$ and earlier as suitable instruments for the differenced values of the original regressors; for example, $\Delta$ $D_{E P V A R} R_{i, t-1}, \Delta V G R_{i, t-1}, \Delta G R_{i, t-1}, \Delta G N I P C_{i, t-1}$, and $\Delta A G E_{i t}$ in this context.

10. The additional mean stationarity condition of $\left(y_{i t}, x_{i t}\right)$ enables use of the lagged first differences of the series $\left(y_{i t}, x_{i t}\right)$ dated $t-1$ as instruments for the untransformed equations in levels. 
cross-sectional units, causing heterogeneous error cross-section dependence. Sarafidis and Robertson (2009) show that the standard DIF-GMM and SYS-GMM estimators are not consistent in the presence of heterogeneous error cross-section dependence; the standard instruments these estimators rely on for lagged values of the dependent variable, in levels or first differences, are invalid.

Under the assumption of heterogeneous error cross-section dependence, Sarafidis, Yamagata, and Robertson (2009) suggest a consistent first-differenced GMM estimator (DIF-GMM-C) and a consistent system GMM estimator (SYS-GMM-C). These two GMM estimators rely on partial instruments consisting of the regressors. More specifically, based on partial moment condition (5) below, the DIF-GMM-C estimator is consistent under the assumption of heterogeneous error cross-section dependence. This also applies to the SYS-GMM-C estimator, which is based on partial moment conditions (5) and (6):

$$
\begin{gathered}
E\left[x_{i}^{t-2}\left(\Delta v_{i t}\right)\right]=0 \\
t=3, \cdots 10 . \\
E\left[\Delta x_{i, t-1}\left(\gamma_{i}+v_{i t}\right)\right]=0 .
\end{gathered}
$$

Sarafidis, Yamagata, and Robertson (2009) have proposed a new test for detecting error cross-section dependence in a linear dynamic panel model (CSD test). Under the null hypothesis of homogeneous error cross-section dependence, the CSD test enables examination of whether any error cross-section dependence remains after time dummy variables are included. ${ }^{11}$ The finite sample simulation-based results in Sarafidis, Yamagata, and Robertson show the good performance of the CSD test, especially for the version based on a system GMM estimator.

\section{EMPIRICAL RESULtS}

This section presents the econometric evidence on the impact of output volatility on genuine savings and its key element, natural resources depletion, and examines the channels through which volatility affects natural resources depletion.

A finite sample correction is made to the two-step covariance matrix using the method developed by Windmeijer (2005) for both the first-differenced

11. The CSD test is the Sargan's difference test based on either the two-step first-differenced GMM estimator or two-step system GMM estimator. The Sargan's difference test statistic based on the two-step first-differenced GMM estimator is the difference between the Sargan statistic for DIF-GMM with a standard set of moment conditions (condition 3) and the Sargan statistic for DIF-GMM-C using a restricted set of moment conditions (condition 5). The Sargan's difference test statistic based on the two-step system GMM estimator is the difference between the Sargan statistic for SYS-GMM with a standard set of moment conditions (conditions 3 and 4) and the Sargan statistic for SYS-GMM-C using a restricted set of moment conditions (conditions 5 and 6). 
GMM estimators and the system GMM estimators under either assumption. This analysis uses only lagged values of $y_{i t}$ and $x_{i t}$ from $t-2$ to $t-4$ as instruments. $^{12}$

For any GMM estimators, three specification tests are conducted to address consistency. The first two are serial correlation tests, which test the null hypothesis of no first-order serial correlation (M1) and no second-order serial correlation (M2) in the residuals in the first-differenced equation. Given that the errors in levels are serially uncorrelated, a significant first-order serial correlation would be expected, but an insignificant second-order correlation would be expected in the first-differenced residuals. The third specification test is a Sargan test of overidentifying restrictions, which examines the overall validity of the instruments by comparing the moment conditions with their sample analogue. For SYS-GMM and SYS-GMM-C, an additional test is carried out. The difference Sargan (Diff-Sargan) test examines the null hypothesis that the lagged differences of the explanatory variables are uncorrelated with the errors in the levels equations, as in Blundell and Bond (1998). ${ }^{13}$

Once the model is well-specified, various tests are used to further examine its properties. A Granger causality test is conducted to examine whether genuine savings or natural resources depletion is Granger-caused by economic volatility. ${ }^{14}$ The point estimates for the long-run effect are also reported with the standard errors approximated using the delta method. However, since the long-run effect is calculated as a nonlinear function of the model parameters, this effect may be imprecisely estimated. To test for unobserved individual effects, a heterogeneity test for the null hypothesis of no heterogeneity is conducted. ${ }^{15}$ Finally, the new CSD tests based on the first-differenced GMM estimators and system GMM estimators are carried out, as explained above.

\section{The Impacts of Volatility on Sustainability}

GENUINE SAVINGS. Did output volatility lead to economic unsustainability during 1979-2008? This section first reports the evidence for the whole sample of 128 countries and then for the model that includes the interaction terms between output volatility and the dummy variables for low-income countries, lower energy-intensity countries, or lower trade-share countries to distinguish the volatility effects on genuine savings across country groups.

12. To avoid the possible overfitting bias associated with the full Arellano and Bond (1991) instrument set, Bowsher (2002) proposes selectively reducing the number of moment conditions for each first-differenced equation.

13. The statistic, called an incremental Sargan test statistic, is the difference between the Sargan statistics for DIF-GMM (or DIF-GMM-C) and the Sargan statistic for SYS-GMM (or SYS-GMM-C).

14. The Sargan statistics for the unrestricted and the restricted models, with the same moment conditions, are compared using an incremental Sargan test statistic, which is asymptotically distributed as $\chi_{\gamma}^{2}$, where $\gamma$ is the number of restrictions.

15. The test also uses an incremental Sargan test statistic, the difference between the Sargan statistic for DIF-GMM (or DIF-GMM-C) and the Sargan statistic for SYS-GMM (or SYS-GMM-C), where the lagged levels are used as instruments in the levels equations. 
Table 1. Output Volatility and Genuine Savings, 1979-2008 (Dependent Variable: Genuine Savings)

\begin{tabular}{|c|c|c|c|c|}
\hline \multirow[b]{2}{*}{ Variable or test } & \multicolumn{2}{|c|}{$\begin{array}{l}\text { Cross-sectional } \\
\text { independence }\end{array}$} & \multicolumn{2}{|c|}{ Cross-sectional dependence } \\
\hline & DIF-GMM & SYS-GMM & DIF-GMM-C & SYS-GMM-C \\
\hline Lag 1 genuine savings & $\begin{array}{c}0.207 \\
(0.406)\end{array}$ & $\begin{array}{l}0.584 \\
(0.000) * * *\end{array}$ & $\begin{array}{c}-0.525 \\
(0.358)\end{array}$ & $\begin{array}{c}0.013 \\
(0.983)\end{array}$ \\
\hline Lag 1 output volatility & $\begin{array}{c}-0.175 \\
(0.360)\end{array}$ & $\begin{array}{l}-0.252 \\
(0.010) * *\end{array}$ & $\begin{array}{c}0.286 \\
(0.557)\end{array}$ & $\begin{array}{c}-0.191 \\
(0.650)\end{array}$ \\
\hline Lag 1 per capita GDP growth & $\begin{array}{c}0.061 \\
(0.715)\end{array}$ & $\begin{array}{c}-0.038 \\
(0.753)\end{array}$ & $\begin{array}{c}0.511 \\
(0.462)\end{array}$ & $\begin{array}{c}0.043 \\
(0.890)\end{array}$ \\
\hline Lag 1 per capita GNI & $\begin{array}{c}-0.012 \\
(0.765)\end{array}$ & $\begin{array}{c}-0.021 \\
(0.311)\end{array}$ & $\begin{array}{c}0.030 \\
(0.779)\end{array}$ & $\begin{array}{c}-0.043 \\
(0.291)\end{array}$ \\
\hline Age dependency & $\begin{array}{c}-0.024 \\
(0.837)\end{array}$ & $\begin{array}{l}-0.208 \\
(0.022) * *\end{array}$ & $\begin{array}{c}-0.172 \\
(0.318)\end{array}$ & $\begin{array}{l}-0.415 \\
(0.033)^{* *}\end{array}$ \\
\hline M1 serial correlation test ( $p$-value) & 0.10 & 0.01 & 0.96 & 0.52 \\
\hline M2 serial correlation test ( $p$-value) & 0.56 & 0.88 & 0.22 & 0.65 \\
\hline Sargan test ( $p$-value) & 0.33 & 0.84 & 0.26 & 0.32 \\
\hline Diff-Sargan test ( $p$-value) & & 1.00 & & 0.46 \\
\hline Granger causality test ( $p$-value) & 0.23 & 0.03 & 0.34 & 0.10 \\
\hline Long-run effect & $\begin{array}{c}-0.22 \\
(0.29)\end{array}$ & $\begin{array}{c}-0.61 \\
(0.28)\end{array}$ & $\begin{array}{c}0.19 \\
(0.25)\end{array}$ & $\begin{array}{c}-0.19 \\
(0.54)\end{array}$ \\
\hline Heterogeneity test ( $p$-value) & & 0.00 & & 0.01 \\
\hline CSD test ( $p$-value) & 0.48 & 1.00 & & \\
\hline Number of observations & 896 & 1,022 & 896 & 1,022 \\
\hline
\end{tabular}

*Significant at the 10 percent level; ** significant at the 5 percent level; *** significant at the 1 percent level.

Note: Numbers in parentheses are the robust $p$-values. Data are for 128 nontransition countries over 1979-2008. See text for variables definitions and data sources and for test descriptions.

Source: Author's analysis based on data described in text.

The CSD tests based on first-differenced GMM estimators and system GMM estimators fail to reject the null hypothesis of homogeneous error cross-section dependence (table 1), suggesting that the assumption of cross-sectional independence is appropriate for this context. The focus is naturally on the DIF-GMM and SYS-GMM estimates. The specification tests indicate that the two models are well specified. The hypothesis of no first-order serial correlation can be rejected but not the hypothesis of no second-order serial correlation. The Sargan tests do not signal that the instruments used in the models are invalid. The Diff-Sargan tests for SYS-GMM cannot reject the null hypothesis of the additional moment conditions being valid, implying that SYS-GMM is a more reliable estimator than the DIF-GMM in this context.

Results for the SYS-GMM estimator suggest that the impact of output volatility on genuine savings is statistically significant and negative. The effect of the age-dependency ratio is also negative at the 5 percent significance level. The Granger Causality test confirms the negative effect of volatility, rejecting 
the null hypothesis at a 3 percent significance level. The long-run effect is greater than the short-run effect.

Under certain circumstances, the CSD test might lack power because it is based on the overidentifying restrictions test statistic, so the results should be interpreted cautiously. The following section examining transmission channels provides evidence of such cross-section dependence.

In principle, the first-differenced GMM and system GMM estimates impose homogeneity on all slope coefficients, under either the cross-sectional independence or cross-sectional dependence assumption. One concern with GMM estimates is that these parameters may be heterogeneous across countries, a contention that is confirmed by the heterogeneity test, which clearly rejects the null hypothesis. This concern is addressed by separately including the interaction term between output volatility and the dummy variables for low-income countries, lower energy-intensity countries, and lower trade-share countries (table 2).

For these regressions, the specification tests (M1, M2, and Sargan) indicate that all six models are well-specified. Diff-Sargan tests further show that SYS-GMM is a more reliable estimator than DIF-GMM for this case. The SYS-GMM estimates confirm the strong negative impact from output volatility to genuine savings. The volatility effect is smaller for lower energy-intensity countries than for the whole sample and for other country groups.

Thus, there is evidence that output volatility is indeed an impediment to global sustainability as measured by genuine savings, especially for low-income countries, lower energy-intensity countries, and lower trade-share countries. This finding points to possible damaging consequences of output volatility for the economy as a whole, consistent with what happened during the global financial crisis of 2007-09. A global credit crunch triggered a sustained period of stress and instability in global financial markets and the worst global recession in generations.

However, the negative impact of volatility on genuine savings (net national savings minus natural resources depletion) is likely driven by the negative impact of volatility on growth and savings, as widely examined in the literature. The question then is whether output volatility depletes natural resources or causes environmental degradation as it impedes growth and savings.

Depletion of NATURAL RESOURCES. Table 3 reports evidence on resource depletion for the entire sample of 128 countries for the model with no interaction terms. Based on the first-differenced GMM estimator, the CSD test clearly rejects the null hypothesis of homogeneous cross-sectional dependence. According to Sarafidis and Robertson (2009), the standard DIF-GMM estimator is not consistent in the presence of heterogeneous error cross-section dependence. As expected, Sargan's test for DIF-GMM rejects the null hypothesis while Sargan's test for DIF-GMM-C fails to reject the null hypothesis and the CSD test rejects the null hypothesis. However, for DIF-GMM-C, the serial correlation test M1 cannot reject the null hypothesis, suggesting that DIF-GMM-C is not reliable. 


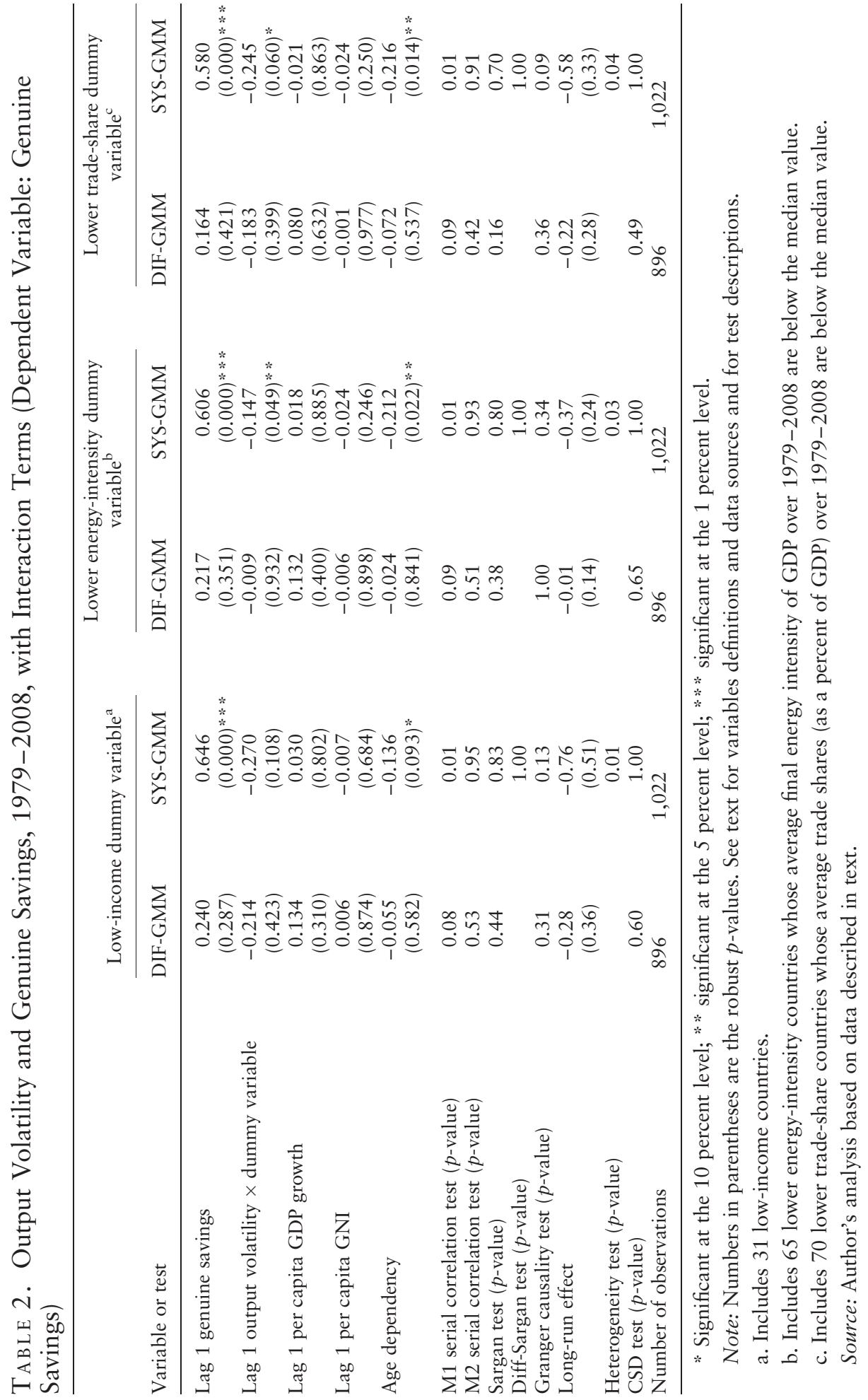


Table 3. Output Volatility and Resource Depletion, 1979-2008 (Dependent Variable: Resource Depletion)

\begin{tabular}{|c|c|c|c|c|}
\hline \multirow[b]{2}{*}{ Variable or test } & \multicolumn{2}{|c|}{$\begin{array}{l}\text { Cross-sectional } \\
\text { independence }\end{array}$} & \multicolumn{2}{|c|}{ Cross-sectional dependence } \\
\hline & DIF-GMM & SYS-GMM & DIF-GMM-C & SYS-GMM-C \\
\hline Lag 1 Resource Depletion & $\begin{array}{c}-0.023 \\
(0.915)\end{array}$ & $\begin{array}{l}-0.418 \\
(0.006) * * *\end{array}$ & $\begin{array}{c}0.058 \\
(0.496)\end{array}$ & $\begin{array}{c}-0.077 \\
(0.623)\end{array}$ \\
\hline Lag 1 Output Volatility & $\begin{array}{c}0.051 \\
(0.470)\end{array}$ & $\begin{array}{l}0.195 \\
(0.055)^{*}\end{array}$ & $\begin{array}{c}0.044 \\
(0.541)\end{array}$ & $\begin{array}{c}0.082 \\
(0.253)\end{array}$ \\
\hline Lag 1 per capita GDP Growth & $\begin{array}{c}0.038 \\
(0.804)\end{array}$ & $\begin{array}{c}0.102 \\
(0.343)\end{array}$ & $\begin{array}{c}0.018 \\
(0.882)\end{array}$ & $\begin{array}{c}0.024 \\
(0.761)\end{array}$ \\
\hline Lag 1 per capita GNI & $\begin{array}{c}0.002 \\
(0.940)\end{array}$ & $\begin{array}{l}-0.046 \\
(0.008)^{* * * *}\end{array}$ & $\begin{array}{c}0.002 \\
(0.926)\end{array}$ & $\begin{array}{l}-0.029 \\
(0.095)^{*}\end{array}$ \\
\hline Age dependency & $\begin{array}{c}-0.026 \\
(0.654)\end{array}$ & $\begin{array}{l}-0.272 \\
(0.001)^{* * *}\end{array}$ & $\begin{array}{c}-0.054 \\
(0.342)\end{array}$ & $\begin{array}{c}-0.104 \\
(0.196)\end{array}$ \\
\hline M1 serial correlation test ( $p$-value) & 0.70 & 0.09 & 0.62 & 0.91 \\
\hline M2 serial correlation test ( $p$-value) & 0.50 & 0.88 & 0.18 & 0.88 \\
\hline Sargan test ( $p$-value) & 0.01 & 0.59 & 0.12 & 0.57 \\
\hline Diff-Sargan test ( $p$-value) & & 1.00 & & 1.00 \\
\hline Granger causality test ( $p$-value) & 0.31 & 0.17 & 0.17 & 0.11 \\
\hline Long-run effect & $\begin{array}{l}0.05 \\
(0.06)\end{array}$ & $\begin{array}{c}0.14 \\
(0.07)\end{array}$ & $\begin{array}{l}0.05 \\
(0.07)\end{array}$ & $\begin{array}{c}0.08 \\
(0.06)\end{array}$ \\
\hline Heterogeneity test ( $p$-value) & & 0.00 & & 0.00 \\
\hline CSD test ( $p$-value) & 0.01 & 0.46 & & \\
\hline Number of observations & 895 & 1,021 & 895 & 1,021 \\
\hline
\end{tabular}

* Significant at the 10 percent level; ** significant at the 5 percent level; *** significant at the 1 percent level.

Note: Numbers in parentheses are the robust $p$-values. Data are for 128 nontransition countries over 1979-2008. Resource depletion is measured by three-year averages of the sum of energy depletion, mineral depletion, and net forest depletion, as defined in the text. See text for variables definitions and data sources and for test descriptions.

Source: Author's analysis based on data described in text.

Based on system GMM estimators, the CSD test cannot reject the null hypothesis, suggesting that SYS-GMM rather than SYS-GMM-C is the appropriate estimator for this context. For SYS-GMM, serial correlation tests M1 and M2 indicate that the null hypothesis of no first-order serial correlation can be rejected, but that the null hypothesis of no second-order serial correlation cannot be rejected. The Sargan tests cannot reject the null hypothesis that the instruments in the model are valid. The Diff-Sargan test cannot reject the null hypothesis that the additional moment conditions are valid, supporting SYS-GMM as the more reliable estimator for this context. The SYS-GMM estimates provide strong evidence of a positive effect of output volatility on natural resources depletion in the global economy. They also provide evidence that per capita GNI and the age-dependency ratio, both significant at the 1 percent level, are important variables. 
Taвle 4. Output Volatility and Resource Depletion, 1979-2008, with Interaction Terms (Dependent Variable: Resource Depletion)

\begin{tabular}{|c|c|c|c|c|}
\hline \multirow[b]{2}{*}{ Variable or test } & \multicolumn{2}{|c|}{$\begin{array}{l}\text { Lower income dummy } \\
\text { variable }^{\mathrm{a}}\end{array}$} & \multicolumn{2}{|c|}{$\begin{array}{l}\text { Lower energy-intensity } \\
\text { dummy variable }{ }^{b}\end{array}$} \\
\hline & DIF-GMM & SYS-GMM & DIF-GMM & SYS-GMM \\
\hline Lag 1 resource depletion & $\begin{array}{r}-0.031 \\
(0.823)\end{array}$ & $\begin{array}{l}-0.412 \\
(0.012) * *\end{array}$ & $\begin{array}{r}-0.058 \\
(0.791)\end{array}$ & $\begin{array}{l}-0.433 \\
(0.010) * * *\end{array}$ \\
\hline Lag 1 output volatility $\times$ dummy variable & $\begin{array}{c}0.030 \\
(0.408)\end{array}$ & $\begin{array}{c}0.124 \\
(0.062) *\end{array}$ & $\begin{array}{c}0.034 \\
(0.618)\end{array}$ & $\begin{array}{l}0.179 \\
(0.052) *\end{array}$ \\
\hline Lag 1 per capita GDP growth & $\begin{array}{c}0.043 \\
(0.581)\end{array}$ & $\begin{array}{c}0.066 \\
(0.522)\end{array}$ & $\begin{array}{c}0.047 \\
(0.724)\end{array}$ & $\begin{array}{c}0.053 \\
(0.582)\end{array}$ \\
\hline Lag 1 per capita GNI & $\begin{array}{c}0.007 \\
(0.761)\end{array}$ & $\begin{array}{l}-0.048 \\
(0.009) * * *\end{array}$ & $\begin{array}{c}0.005 \\
(0.791)\end{array}$ & $\begin{array}{l}-0.050 \\
(0.008) * * *\end{array}$ \\
\hline Age dependency & $\begin{array}{l}-0.031 \\
(0.601)\end{array}$ & $\begin{array}{l}-0.288 \\
(0.001) * * *\end{array}$ & $\begin{array}{r}-0.036 \\
(0.531)\end{array}$ & $\begin{array}{l}-0.280 \\
(0.001) * * *\end{array}$ \\
\hline M1 serial correlation test ( $\mathrm{p}$-value) & 0.67 & 0.13 & 0.83 & 0.11 \\
\hline M2 serial correlation test ( $\mathrm{p}$-value) & 0.46 & 0.78 & 0.54 & 0.63 \\
\hline Sargan test ( $\mathrm{p}$-value) & 0.02 & 0.53 & 0.01 & 0.42 \\
\hline Diff-Sargan test (p-value) & & 1.00 & & 1.00 \\
\hline Granger causality test ( $\mathrm{p}$-value) & 0.14 & 0.60 & 0.55 & 0.40 \\
\hline Long-run effect & $\begin{array}{c}0.03 \\
(0.03)\end{array}$ & $\begin{array}{c}0.09 \\
(0.04)\end{array}$ & $\begin{array}{c}0.03 \\
(0.06)\end{array}$ & $\begin{array}{c}0.13 \\
(0.06)\end{array}$ \\
\hline Heterogeneity test ( $\mathrm{p}$-value) & & 0.00 & & 0.00 \\
\hline CSD test ( $\mathrm{p}$-value) & 0.01 & 0.30 & 0.03 & 0.25 \\
\hline Number of observations & 895 & 1,021 & 895 & 1,021 \\
\hline
\end{tabular}

*Significant at the 10 percent level; ** significant at the 5 percent level; *** significant at the 1 percent level.

Note: Numbers in parentheses are the robust $p$ values. See text for variables definitions and data sources and for test descriptions.

a. Includes 31 low-income countries and 63 middle income countries.

b. Includes 65 lower energy-intensity countries whose average final energy intensity of GDP over 1979-2008 are below the median value.

Source: Author's analysis based on data described in text.

Table 4 looks at whether these findings are robust to the inclusion of interaction terms between output volatility and the lower income countries dummy variable or the lower energy-intensity dummy variable. The specification tests (M1, M2, and Sargan) indicate that the SYS-GMM and SYS-GMM-C models are well-specified. The Diff-Sargan test further shows that SYS-GMM is a more reliable estimator than the DIF-GMM for this case. The SYS-GMM estimates provide evidence for a strong positive impact from output volatility to natural resources depletion. Per capita GNI and the age-dependency ratio also have a statistically significant negative impact on natural resources depletion. The effect of volatility on natural resources depletion is smaller for the lower income countries than for the whole sample and for the lower energy-intensity countries. 
In summary, output volatility has damaging effects on genuine savings, likely due to the positive impact on natural resources depletion in addition to the negative impact of output volatility on net national savings suggested in the literature. The significant effects are greater in low-income countries, lower energy-intensity countries, and lower trade-share countries, suggesting that these countries are especially vulnerable to macroeconomic shocks. The results are robust to the use of alternative estimation methods and are not due to unobserved heterogeneity or reverse causality.

\section{The Channels}

What are the underlying channels through which volatility affects sustainable development? This section focuses on natural resources depletion as the dependent variable.

Table 5 presents evidence on whether output volatility affects natural resources depletion through either financial development or investment share. The financial development channel considered is the liquidity liability ratio. Based on first-differenced GMM and system GMM estimators, the CSD tests clearly reject the null hypothesis of homogeneous cross-sectional dependence, suggesting that DIF-GMM-C and SYS-GMM-C are consistent estimators, unlike DIF-GMM and SYS-GMM. For DIF-GMM-C, serial correlation tests M1 and M2 indicate that the null hypothesis of no first-order serial correlation can be rejected but the hypothesis of no second-order serial correlation cannot. The Sargan tests cannot reject the null hypothesis that the instruments in the model are valid. For SYS-GMM-C, M1 cannot reject the null hypothesis. Thus the analysis focuses on the DIF-GMM-C estimates.

The DIF-GMM-C estimates clearly indicate that output volatility is no longer significant while the liquidity liability ratio is significant. This result is supported by the Granger causality test for the effect of output volatility, which cannot reject the null hypothesis. Apparently, the liquidity liability ratio picks up the effect of output volatility on natural resources depletion and is the channel through which output volatility induces natural resources depletion, thereby impairing sustainability.

What about the investment ratio channel? With the inclusion of the investment ratio, the DIF-GMM, DIF-GMM-C, and SYS-GMM models are no longer well-specified. The specifications tests are in general satisfactory for the SYS-GMM estimator. Based on first-differenced GMM and system GMM estimators, the CSD test clearly rejects the null hypothesis, further suggesting that SYS-GMM is a consistent estimator. Investment share is insignificant, while output volatility continues to be significant. There is no evidence that the investment ratio picks up the effect of output volatility on natural resources depletion, but this does not necessarily rule out the possibility that the investment ratio is a channel for output volatility to affect sustainability because several of the models are not well specified when the investment ratio is added. Further research is needed. 


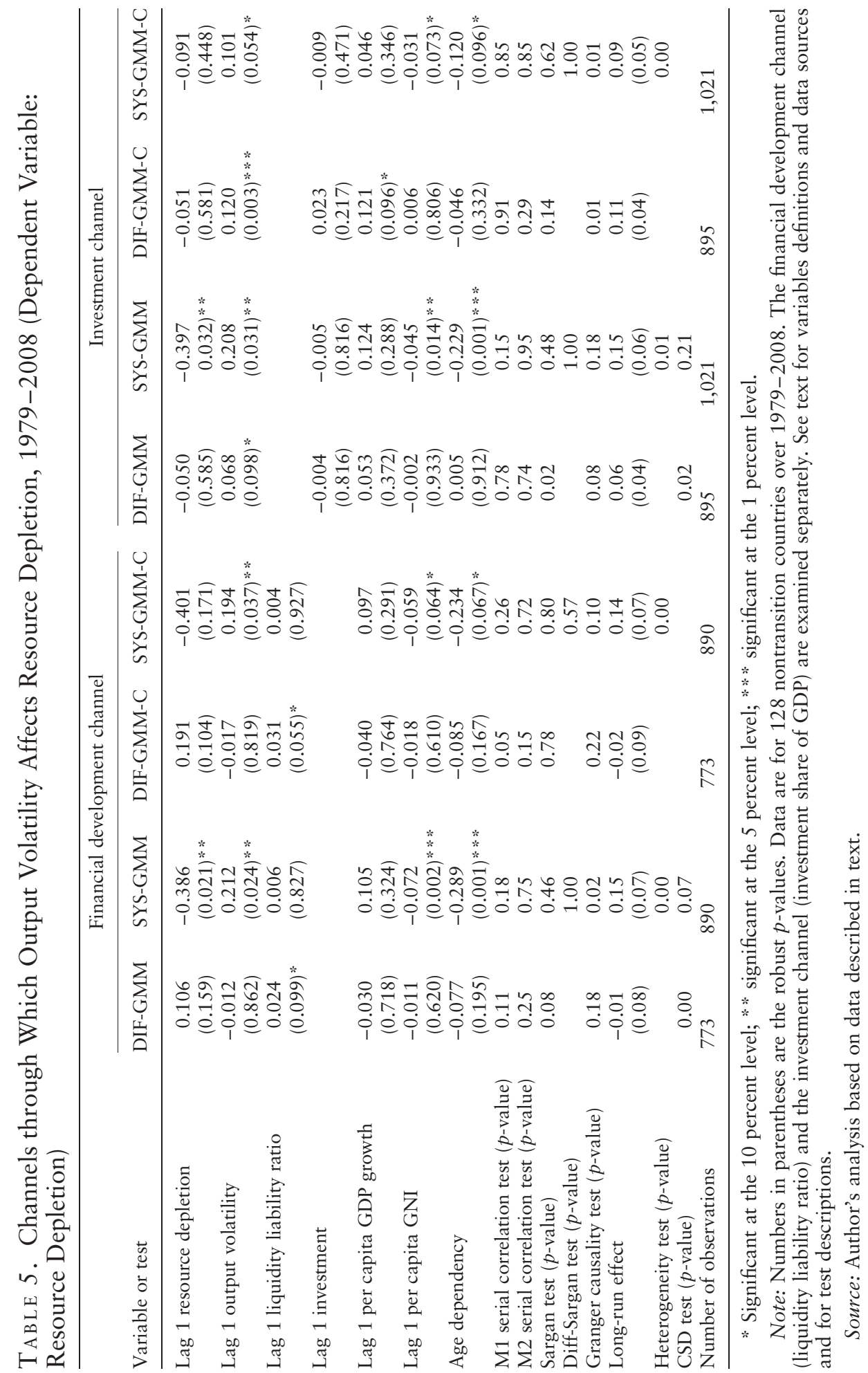


Final energy intensity and energy consumption per capita were also examined as potential transmission channels. Neither was found to be significant. This is another interesting area for further research.

\section{Summary and Conclusions}

In sum, the interaction between global financial markets and the wider economy significantly influences sustainable development. Through this financial development channel, specifically the liquidity liability ratio, output volatility affects natural resources depletion, a key component of genuine savings. This analysis sheds light on the interaction between the financial crisis and economic downturns during the 2007-09 global financial crisis. After the collapse of the U.S. subprime mortgage market in 2007 and the failure of Lehman Brothers in 2008, the global economic downturn caused by the credit crunch led to rising credit risk and uncertainty in the financial system. This intensified the already sharp drop in global demand, with adverse implications for sustainable growth and sustainable exploitation of natural resources.

There is also evidence of cross-country dependence through the financial development channel. Macroeconomic volatility or financial crisis in one country tends to spread rapidly to other financial markets, perhaps reflecting the cross-border financial links typically associated with financial markets. Lower income countries, lower energy-intensity countries, and lower tradeshare countries are in general more vulnerable to macroeconomic volatility or shocks. Increasing the resilience of these countries to financial crisis and economic volatility should help to build a sustainable global economy. Understanding the nature of volatility and how to manage its consequences should be of considerable interest, especially to developing countries.

However, the ability of these countries to tackle volatility might be constrained by an underdeveloped financial sector, weak institutions, and other political economy considerations. Empirical research continues to show that underdeveloped financial sectors and weak institutions in developing countries can amplify the adverse effects of volatility on long-run growth and sustainable development and result in persistent long-run development problems. Governments should aim to liberalize the financial sector and strengthen capacities to mobilize and manage financial resources while ensuring adequate regulation and supervision and delivering public services more effectively. In addition, government actions to expand energy-saving development and strengthen macroeconomic fundamentals could support sustainable development.

Internationally, supportive frameworks are needed to facilitate financial development, energy savings, climate change adaptation and mitigation, and a low carbon economy. Dedicated resources for development should be made available for vulnerable countries and people around the world to enable countries to cope with economic volatility and crises and improve safety nets and basic services such as health and education. 


\section{REFERENCES}

Aizenman, Joshua, and Brian Pinto. 2005. "Overview." In Joshua Aizenmann and Brian Pinto, eds., Managing Economic Volatility and Crises. Cambridge: Cambridge University Press.

Arellano, Manuel, and Stephen Bond. 1991. "Some Tests of Specification for Panel Data: Monte Carlo Evidence and an Application to Employment Equations." Review of Economic Studies 58: 277-97.

Arellano, Manuel, and Olympia Bover. 1995. "Another Look at the Instrumental-variable Estimation of Error-components Models." Journal of Econometrics 68: 29-51.

Aysan, Ahmet F. 2007. "The Effects of Volatility on Growth and Financial Development through Capital Market Imperfections." METU Studies in Development 34(1): 1-18.

Bai, Jushan. 2009. "Panel Data Models with Interactive Fixed Effects." Econometrica 77(4): 1229-79.

Barbier, Edward B. 2009. "A Global Green New Deal." Report prepared for the Green Economy Initiative and the Division of Technology, Industry and Economics of the UN Environment Programme. Department of Economics and Finance, University of Wyoming, Laramie.

Blundell, Richard, and Stephen Bond. 1998. "Initial Conditions and Moment Restrictions in Dynamic Panel Data Models.” Journal of Econometrics 87: 115-43.

Bowsher, Clive G. 2002. "On Testing Over-identifying Restrictions in Dynamic Panel Data Models." Economics Letters 77: 211-20.

Canton, Erik. 2002. "Business Cycles in a Two-sector Model of Endogenous Growth." Economic Theory 19: 477-92.

Committee of Ten. 2009. "Impact of the Crisis on African Economies-Sustaining Growth and Poverty Reduction, African Perspectives and Recommendations to the G20.” Report to the British Prime Minister, Gordon Brown, March 17. African Development Bank, the African Union and the United Nations Economic Commission for Africa, Abidjan, Côte d'Ivoire.

Dauvergn, Peter. 1999. "The Environmental Implications of Asia's 1997 Financial Crisis." IDS Bulletin 30(3): 31-42.

Dietz, Simon, Eric Neumayer, and Indra de Soysa. 2007. "Corruption, the Resource Curse and Genuine Saving." Environment and Development Economics 12: 33-53.

Enerdata. 2010. Global Energy Market Data. Retrieved December 2010 from www.enerdata.fr.

Gaveau, David L. A., Matthew Linkie, Patrice Levangd, and Nigel Leader-Williams. 2009. "Three Decades of Deforestation in Southwest Sumatra: Effects of Coffee Prices, Law Enforcement, and Rural Poverty." Biological Conservation 142(3): 597-605.

Ghosh, Atish R., and Jonathan D. Ostry. 1997. "Macroeconomic Uncertainty, Precautionary Saving, and the Current Account." Journal of Monetary Economics 40(1): 121-39.

Grier, Kevin B., and Gordon Tullock. 1989. "An Empirical Analysis of Cross-national Economic Growth, 1951-1980." Journal of Monetary Economics 24: 259-76.

Hamilton, Katherine, Milo Sjardin, Molly Peters-Stanley, and Thomas Marcello. 2010. "Building Bridges: State of the Voluntary Carbon Markets 2010." Washington, D.C. and New York: Ecosystem Marketplace and Bloomberg New Energy Finance.

Heston, Alan, Robert Summers, and Bettina Aten. 2009. Penn World Table, version 6.3. Center for International Comparisons, University of Pennsylvania, Philadelphia.

Hnatkovska, Viktoria, and Norman Loayza. 2005. "Volatility and Growth.” In Joshua Aizenmann and Brian Pinto, eds., Managing Economic Volatility and Crises. Cambridge: Cambridge University Press.

Huang, Yongfu. 2010. Determinants of Financial Development. Basingstoke, U.K.: Palgrave Macmillan Press.

Intergovernmental Panel on Climate Change (IPCC). 2001. Climate Change 2001. Synthesis Report. Cambridge: Cambridge University Press.

Kasa, Sjur, and Lars Otto Næss. 2005. "Financial Crisis and State-NGO Relations: The Case of Brazilian Amazonia, 1998-2000.” Society \& Natural Resources 18(9): 791-804. 
Kharroubi, Enisse. 2007. “Crises, Volatility, and Growth.” World Bank Economic Review 21(3): 439-60.

Kittiprapas, Sauwalak. 2002. "Social Impacts of Financial and Economic Crisis in Thailand.” Regional Project on the Social Impact of the Asian Financial Crisis. East Asian Development Bank: Manila.

Koren, Miklós, and Silvana Tenreyro. 2007. "Volatility and Development." Quarterly Journal of Economics 122(1): 243-87.

Kormendi, Roger, and Philip Meguire. 1985. "Macroeconomic Determinants of Growth: Cross-country Evidence." Journal of Monetary Economics 16(2): 141-63.

Lin, J. Yifu. 2009. "Learning from the Past to Reinvest the Future." Address at the Annual Bank Conference on Development Economics, June 22-24, Seoul.

Loayza, Norman V., Romain Rancière, Luis Servén, and Jaume Ventura. 2007. "Macroeconomic Volatility and Welfare in Developing Countries: An Introduction." World Bank Economic Review 21(3): 343-57.

OECD/IEA (Organisation for Economic Co-operation and Development/International Energy Agency). 2009. "The Impact of the Financial and Economic Crisis on Energy Investment." Background paper for the G-8 Energy Ministers’ Meeting, May 24-25, L’Aquila, Italy.

Ramey, Garey, and Valerie A. Ramey. 1995. "Cross Country Evidence on the Link between Volatility and Growth.” American Economic Review 85(5): 1138-51.

Sandmo, Agnar. 1970. "The Effect of Uncertainty on Saving Decisions." The Review of Economic Studies 37(3): 353-60.

Sarafidis, Vaslis, and Donald Robertson. 2009. "On the Impact of Error Cross-sectional Dependence in Short Dynamic Panel Estimation.” Econometrics Journal 12(1): 62-81.

Sarafidis, Vaslis, Takashi Yamagata, and Donald Robertson. 2009. "A Test of Cross Section Dependence for a Linear Dynamic Panel Model with Regressors.” Journal of Econometrics 148(2): 149-61.

United Nations General Assembly. 2005. “2005 World Summit Outcome.” Final document. A/60/L.1. New York.

Windmeijer, Frank. 2005. "A Finite Sample Correction for the Variance of Linear Efficient Two-step GMM Estimators.” Journal of Econometrics 126(1):25-51.

Wolf, Holger. 2005. "Volatility: Definitions and Consequences." In Joshua Aizenmann and Brian Pinto, eds., Managing Economic Volatility Crises. Cambridge: Cambridge University Press.

World Bank. 2010a. Financial Development and Structure Database. Washington, D.C.

—. 2010b. World Development Indicators 2010 Database. Washington, D.C.

2011. World Bank List of Economies. Retrieved January 2011 from http://search.worldbank. org/all?qterm $=1$ list $\% 20$ of $\% 20$ economies.

World Commission on Environment and Development. 1987. Our Common Future. Oxford: Oxford University Press. 